\title{
Involvement in Agro-Tourism Activities among Communities in Desa Wawasan Nelayan Villages on the East Coast of Malaysia
}

\author{
Zaim Fahmi ${ }^{1}$, Azimi Hamzah ${ }^{1}$, Mahazan Muhammad ${ }^{1}$, Sulaiman Md. Yassin ${ }^{1}$, Bahaman Abu Samah ${ }^{1}$, Jeffrey \\ Lawrence D'Silva ${ }^{1} \&$ Hayrol Azril Mohamed Shaffril ${ }^{1}$ \\ ${ }^{1}$ Institute for Social Science Studies, Universiti Putra Malaysia, Malaysia \\ Correspondence: Azimi Hamzah, Institute of Social Science Studies, Universiti Putra Malaysia, 43400 Serdang, \\ Selangor Darul Ehsan, Malaysia. Tel: 60-3-8947-1868. E-mail: majudesa.desa@gmail.com
}

Received: November 4, 2012 Accepted: November 26, 2012 Online Published: January 28, 2013

doi:10.5539/ass.v9n2p203 URL: http://dx.doi.org/10.5539/ass.v9n2p203

The research is financed by Research University Grant Scheme (Scheme 1) sponsored by Universiti Putra Malaysia.

\begin{abstract}
Over the years, most developing countries across the globe have identified agro-tourism activities as being able to assist their respective country's development. Malaysia is no exception to this; the country has emphasized agro-tourism as a significant tool of development and poverty eradication, and perhaps, at the same time, a key strategy by which to address the problem of rural migration. The Fisheries Development Authority of Malaysia, also known as LKIM, has been playing a part in responding to the government's call to develop the agro-tourism industry in Malaysia. LKIM has taken steps towards formulating an agro-tourism program for fishing communities called Desa Wawasan Nelayan. The purpose of this paper is to determine the level of involvement in agro-tourism amongst fishing communities in the east coast region of Malaysia. The study was conducted amongst 220 respondents from two villages in Terengganu and Kelantan. The findings of the research reveal that despite the government's intervention in promoting agro-tourism activities throughout the nation, the level of involvement amongst respondents is still at a moderate level.
\end{abstract}

Keywords: agro-tourism, involvement, Desa Wawasan Nelayan, community development

\section{Introduction}

Tourism involves three main elements: the economy, society and nature. Mass tourism is, to date, the most profitable type of tourism worldwide, but this type of tourism also comes with an adverse impact on social and environmental aspects (Williams et al., 1997). The two key parties that are directly involved in tourism activities are tourists and locals. Tourists are groups of individuals who seek new experiences, goods, and excitement via the places they visit, while the local population is clusters of people that often experience a dilemma with respect to tourism, as these activities usually provide opportunities and threats at the same time. The opportunities arise in terms of improved income, while the threats come from adverse effects on aspects of the area's social fabric, and the environment (Tsartas, 2003). This finding is consistent with the scenario in Malaysia, where the tourism industry is the second largest contributor after manufacturing. In 2008 alone, Malaysia recorded 22.05 million tourist arrivals, and the tourism industry contributed RM 49.6 billion (USD 13.4 billion) of revenue. Therefore, in realizing the importance of the tourism industry to the national economy, the government has taken various initiatives to further develop it, and has put particular emphasis on the development of the industry through the Ministry of Tourism. There are various programs conducted by the government to further promote tourism activities, for instance the "Rural Tourism Master Plan", implemented in 2001, which was formulated to further develop agro-tourism or the homestay industry as a key driver of rural community development. In addition, the government's commitment to this area is demonstrated within the Ninth Malaysian Plan, in which rural tourism is identified as one of the mechanisms that will ensure the success of community development. Due to the negative effects arising from mass tourism, alternative forms of tourism are gaining prominence, in which products and services of comparable quality are provided, while providing advantages in terms of offering a natural experience and personal contact between customers (tourists) and service providers (local people) (Anthopolou et al., 2000). One of the alternative forms of tourism is agro-tourism, which is a subset of rural 
tourism (Lopez and Garcia, 2006).

Agro-tourism basically refers to tourism activities conducted in rural areas by groups of individuals who are involved in agriculture, and may be defined as an alternative form of tourism that promotes recreational activities amongst tourists who pay a certain sum of money for firsthand experience of the living environment within the farming community, either as resident guests or day trippers (Busby and Rendle, 2000). Agro-tourism activities are not only beneficial in term of economics to the farming community, but also assist in addressing the problem of unemployment and rural migration, since the younger generation has the opportunity to generate income without the need to migrate to a bigger city (Dernoi, 1983). This type of alternative tourism plays an important role in ensuring rural development due to the tremendous positive impact on farmers. Agro-tourism is an aspect to be emphasized in this study, as it can be classified as an effective development strategy within the context of rural communities due to its substantial positive impact on the livelihoods of the farmers (Hjalager, 1997). Thus, this study will focus on the involvement of fishermen in agro-tourism activities, which are derived as key findings from stakeholders in the industry.

Community involvement is a very important aspect in agro-tourism activities, and may be defined as "a form of voluntary action through which individuals take the opportunity to uphold social responsibility" (Tosun, 2000). Similar to any other development projects, there will be those who support and those who oppose agro-tourism activities, based on their very own distinctive views. Various reasons are put forward by those who are in opposition. In accordance with Tosun's (2006) findings, the majority (more than $80 \%$ ) of communities in local destinations are eager to take a leading role, either directly or indirectly, in agro-tourism activities. However, it is up to the authorities to improve the participants' confidence levels and ensure the success of agro-tourism projects, which will improve community involvement in this industry. In the Malaysian context, a recent study conducted in the state of Kedah discovered that positive benefits from agro-tourism activities were not enjoyed by most of the local residents due to their lack of involvement and their inability to respond to new job opportunities created by this industry (Jun, 2005). This situation may be explained by authorities' ignorance of the importance of encouraging locals to get involved in putting forth ideas and deciding which programs most suit their living environment (Akama, 1996).

\section{Methodology}

The sampling design that was adopted for this study was simple random sampling. In order to obtain the minimum sample size required for the data analysis, $G^{*}$ power software was utilized. This procedure was essential in order to obtain statistically different results for each test carried out. Thus, 220 respondents were selected for the purpose of this study with the assistance of a table of random numbers. These respondents were selected amongst two distinct Desa Wawasan Nelayan villages in the east coast region of peninsular Malaysia, namely Desa Wawasan Nelayan Rhu 10, located in Terengganu, and Desa Wawasan Nelayan Pantai Suri, in Kelantan. Desa Wawasan Nelayan villages are fishing villages listed by LKIM which has the potential to further developed as an agro-tourism attraction. The instrument used in this study was a survey questionnaire, which employed five-point Likert scales with 1 representing "strongly disagree", 2 representing "disagree", 3 representing "somewhat disagree", 4 representing "agree" and 5 representing "strongly agree". To gain the category of involvement, the maximum number of mean score (5.0) was divided equally into three categories namely low (1.00-2.33), moderate (2.34 to 3.67) and high (3.68 to 5.00). In order to facilitate the data collection process, each respondent was assisted by enumerators in completing the questionnaire.

\section{Results}

\subsection{Respondents Demographic Data}

A total of 220 questionnaires were obtained from the data collection process and analyzed for this research. The respondent population comprised $40.9 \%$ males and $59.1 \%$ females, thus the gender distribution amongst the respondents can be considered balanced. A total of $36.8 \%$ of the respondents come from the age group 41 to 60 ; $34.1 \%$ were aged between 21 to $40 ; 14.1 \%$ were aged between 61 to 80 ; while the remaining $15 \%$ were aged less than 20. In terms of highest level of education, the majority (33.6\%) of respondents had obtained an SPM/SPMV/MCE (Note 1) certificate, followed by $25 \%$ who had completed primary school education, $18.2 \%$ who did not have any formal education, $17.3 \%$ who possessed PMR/SRP/LCE (Note 2), 1.8\% who held a certificate demonstrating a particular skill, $2.7 \%$ who had a diploma, and $1.4 \%$ who had been educated to university level or held a degree (Table 1). 
Table 1. Demographic profile $(n=220)$

\begin{tabular}{|c|c|c|c|c|}
\hline Demographic Profile & Frequency & Percentage & Mean & SD \\
\hline \multicolumn{5}{|l|}{ Gender } \\
\hline Male & 90 & 40.9 & & \\
\hline Female & 130 & 59.1 & & \\
\hline Age & & & 41 & 16.90 \\
\hline$<20$ years & 33 & 15.0 & & \\
\hline $21-40$ years & 75 & 34.1 & & \\
\hline $41-60$ years & 81 & 36.8 & & \\
\hline $61-80$ years & 31 & 14.1 & & \\
\hline \multicolumn{5}{|l|}{ Education Level } \\
\hline Non-Formal Education & 40 & 18.2 & & \\
\hline Primary School & 55 & 25.0 & & \\
\hline PMR/SRP/LCE & 38 & 17.3 & & \\
\hline SPM/SPMV/MCE & 74 & 33.6 & & \\
\hline Skill Certificate & 4 & 1.8 & & \\
\hline STPM/Diploma & 6 & 2.7 & & \\
\hline Bachelor's/Master's/PhD & 3 & 1.4 & & \\
\hline
\end{tabular}

3.2 Community Involvement in Agro-Tourism Activities in the East Coast Region of Malaysia

Table 2 shows the mean score for each statement used to measure community involvement in agro-tourism activities in the east coast region of Malaysia. The highest mean score obtained $(\mathrm{M}=4.45)$ was for the statement "I am concerned about the cleanliness of the village". Meanwhile, the lowest mean score $(\mathrm{M}=1.44)$ was recorded for the statement "I am involved in tourism activities here".

Table 2. Community involvement in agro-tourism activities in the east coast region of Malaysia

\begin{tabular}{lcc}
\hline \multicolumn{1}{c}{ Statement } & Mean & $\begin{array}{c}\text { Standard } \\
\text { deviation }\end{array}$ \\
\hline Overall mean score & $\mathbf{2 . 7 5}$ & \\
I am involved in fishing activities in this area. & 2.23 & 1.68 \\
I am involved in tourism activities here. & 1.44 & 1.02 \\
I am involved in agricultural activities other than fishing in this area. & 1.50 & 1.07 \\
I am often involved in meetings relating to the development of agro-tourism & 2.36 & 1.48 \\
activities in this area. & 2.54 & 1.46 \\
I work with relevant agencies to strengthen tourism activity here. & 1.58 \\
$\begin{array}{l}\text { My participation in tourism activities is not influenced by anyone, it is my own } \\
\text { desire to be involved. }\end{array}$ & 2.85 & 1.45 \\
I often promote local products to tourists. & 3.27 & 1.57 \\
I am involved in entrepreneurial activities in this area (local products, business, \\
etc.). & 2.75 & \\
I am involved in environmental conservation activities in this area (e.g. cleaning the & 4.10 & 1.03 \\
beaches). & 4.45 & 0.68 \\
I am concerned about the cleanliness of the village. & & \\
\hline
\end{tabular}

3.3 Level of Involvement in Agro-Tourism Activities in the East Coast Region of Peninsula Malaysia

To gain the overall mean score, the cumulative mean scores for the 10 statements were obtained. The resulting mean score was then divided into three levels, namely low (1.00-2.33), moderate (2.34-3.67) and high (3.68-5.00). The overall mean score for level of involvement is 2.75, with an SD of .754. The overall mean score 
depicted that the respondents have a moderate level of involvement in agro-tourism activities; however, a total of $11.0 \%$ of the respondents demonstrated a high level of involvement.

Table 3. Level of involvement in agro-tourism activities in the east coast region of Peninsula Malaysia

\begin{tabular}{lllll}
\hline & Frequency & Percentage & Mean & SD \\
\hline Low (1.00-2.33) & 75 & 34.1 & $\mathbf{2 . 7 5}$ & $\mathbf{. 7 5 4}$ \\
Moderate (2.34-3.67) & 119 & 54.1 & & \\
High (3.68-5.00) & 26 & 11.0 & & \\
\hline
\end{tabular}

\section{Discussion}

The main purpose of this research is to examine the involvement of fishermen in the agro-tourism activities within Desa Wawasan Villages in the east coast region of Peninsular Malaysia. Although this project, which is an initiative by the government with the assistance of LKIM, has been successful to some extent in enlightening the community about the existence of a new industry that can generate income, the findings reveal that, surprisingly, the overall participation rate of the locals is only moderate. This finding indicates that despite the potential of agro-tourism programs as a tool for poverty eradication in rural areas, their implementation as a rural development strategy is currently inefficient in improving the living standards of rural communities. These findings are consistent with those of previous studies conducted in developing countries, where there are several limitations in promoting community involvement in tourism activities. This is proven as the low and moderate mean scores for items regarding respondents' involvement in meetings relate to the development of agro-tourism activities, engagement in working with relevant agencies in strengthening tourism activity, and participation in entrepreneurial activities related to agro-tourism. This may be due to the centralization of power by authorities in managing tourism projects. This situation is further complicated by the capacity of local people, who usually have low incomes and lack awareness about the importance of their participation in agro-tourism projects (Tosun, 2000). As a result; the local population has failed to benefit from agro-tourism programs in terms of employment and entrepreneurship. Most of the respondents agreed with statements regarding concerns about the cleanliness of their villages. This finding is supported by the literature review, in which one of the positive impacts of tourism activity on the social capital development of a community is to create awareness regarding the importance of environmental conservation (Sijlbing, 2010).

\section{Conclusion}

Based on the findings in the study, the respondents indicated a moderate level of involvement in agro-tourism programs, and this could undermine the development of the tourism industry. The involvement of local residents in the success of tourism activities should be planned carefully so that no matters arise that shall hinder and further damage the industry. Involvement of the local population is essential, as the tourism industry relies solely on local cultures and natural resources, and requires the involvement of the local population to administer it (Lillywhite and Lillywhite, 1991). Further studies regarding elements such as forms of participation and involvement, and the impact of factors are crucial in order to improve the level of involvement in agro-tourism activities.

\section{References}

Akama, J. S. (1996). Western environmental values and nature-based tourism in Kenya. Tourism Management, 17(8), 567-574. http://dx.doi.org/10.1016/S0261-5177(96)00077-5

Anthopoulou, T. (2000). Agrotourism and the rural environment: constraints and opportunities in the Mediterranean less-favoured areas. In Briassoulis, H., \& van der Straaten, J. (Eds.), Tourism and the Environment: Regional, economic, cultural and policy issues 2000 (pp. 357-373).

Busby, G., \& Rendle, S. (2000). The transition from tourism on farms to farm tourism. Tourism Management, 21(8), 635-642. http://dx.doi.org/10.1016/S0261-5177(00)00011-X

Dernoi, L. A. (1983). Farm tourism in Europe. Tourism Management, 12(3), 155-166. http://dx.doi.org/10.1016/0261-5177(83)90060-2

Hjalager, A. M. (1997). Agriculture diversification into tourism: Evidence of a European Community development programme. Tourism $103-111$. http://dx.doi.org/10.1016/0261-5177(95)00113-1. 
Jun, L. W. (2005). Community decision making; participation in development. Annals of Tourism Research, 33(1), 132-143. http://dx.doi.org/10.1016/j.annals.2005.07.003

Lillywhite, M., \& Lillywhite, L. (1991). Low impact tourism: coupling natural/cultural resource conservation, economic development, and the tourism industry. In Kusler, J. A. (Ed.), Ecotourism and Resource Conservation: A Collection of Papers (Vol. 1, pp. 89).

Lopez, E. P., \& Garcia, F. J. C. (2006). Agro tourism, sustainable tourism and ultraperipheral areas: the case of Canary Island. PASOS. Revista de Turism of Patrimonia Cultural, 4(1), 85-97.

Sijlbing, H. A. (2010). Does sustainable tourism offer solutions for the protection of the Amazon rainforest in Suriname? Journal of Worldwide Hospitality and Tourism Theme, 2(2), 192-200. http://dx.doi.org/10.1108/17554211011037886

Tosun, C. (2000). Limit to community participation in the tourism development process in developing countries. Tourism Management, 21, 613-633. http://dx.doi.org/10.1016/S0261-5177(00)00009-1.

Tosun, C. (2006). Expected nature of community participation in tourism development. Tourism Management, 27, 493-504. http://dx.doi.org/10.1016/j.tourman.2004.12.004.

Tsartas, P. (2003). Tourism development in Greel insular and coastal areas: sociocultural changes and crucial

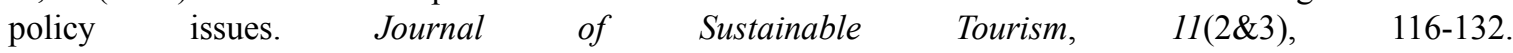
http://dx.doi.org/10.1080/09669580308667199

Williams, A. M., King. R., \& Warnes, A. M. (1997). A place in the sun: international retirement migration from northern to southern Europe. European Urban and Regional Studies, 4, 15-34. http://dx.doi.org/10.1177/096977649700400202.

\section{Notes}

Note 1. PMR/SRP/LCE refers to Malaysian Lower Education Certificate.

Note 2. SPM/SPMV/MCE refers to Malaysian Higher Education Certificate and Malaysian Vocational Certificate. 